\title{
Perianal hair as an unusual presentation of non-classical congenital adrenal hyperplasia
}

\author{
J Sujatha Gopal-Kothandapani, ${ }^{1}$ Anjali Petkar, ${ }^{2}$ Elaine O'Shea, ${ }^{3}$ Indraneel Banerjee ${ }^{1,4}$
}

${ }^{1}$ Department of Paediatric Endocrinology, Royal Manchester Children's Hospital, Manchester, UK ${ }^{2}$ Department of Paediatrics, Tameside General Hospital, Manchester, UK

${ }^{3}$ Department of Paediatric Endocrinology, Manchester Children's Hospital,

Manchester, UK

${ }^{4}$ Faculty of Medical and Human Sciences Centre, University of Manchester, Manchester, UK

\section{Correspondence to}

Dr Indraneel Banerjee, Indi. Banerjee@manchester.ac.uk

\section{To cite:}

Gopal-Kothandapani JS,

Petkar A, O'Shea E, et al. BMJ Case Rep Published

online: [please include Day

Month Year] doi:10.1136/

bcr-2013-010123

\section{DESCRIPTION}

A 6-year-old girl was referred with a 1 year history of 'strings in her bottom'. Her parents were unrelated and white Caucasian. Pregnancy and birth history were unremarkable. Postnatal examination had shown normal female genitalia. At referral, her height was on the 50th centile, while her weight was on the 98th centile. Her blood pressure was normal. She did not have excessive skin or mucosal pigmentation. In the assessment of puberty, there was no breast development. Two dark hairs were present over the labia majora, but none were noted over the mons pubis. The clitoris was marginally enlarged, but there was no posterior labial fusion. Long, dark and coarse hairs were noted in the perianal area, with perineal extension (figure 1). Axillary hairs were not present.

Endocrine investigations revealed suboptimal cortisol levels $(403 \mathrm{nmol} / \mathrm{L})$ to stimulation, with peak $17-\mathrm{OH}$ progesterone $>100 \mathrm{nmol} / \mathrm{L}$, suggesting the diagnosis of 21 hydroxylase congenital adrenal hyperplasia (CAH), with no evidence for salt loss. Genetic testing showed heterozygous mutations (c.290-13C $>\mathrm{G}$ and c.814G $>\mathrm{T}$ ) in CYP21A2, with normal gene copy number, confirming the diagnosis of non-classical $\mathrm{CAH}^{1}{ }^{1}$ Oral hydrocortisone was started on the basis of a history of lethargy and suboptimal cortisol to stimulation.

Children with non-classical CAH usually present with pubic hair and enlarging clitoris owing to androgen excess. Perianal hair has not been reported as a presenting feature in this condition. Our case highlights the need to look for androgendependent hairs beyond the mons pubis, in the perianal area to consider the diagnosis of $\mathrm{CAH}$, a potentially life-threatening condition, if untreated.

\section{Learning points}

- In early to mid childhood, puberty examination should include the inspection of the perianal area for the presence of coarse hair as a feature of significant androgen excess.

- Although pubic hair is usually seen in virilising congenital adrenal hyperplasia, perianal hair may be the first manifestation of androgen excess.

- Perianal hair may alert the clinician to the possibility of non-classical congenital adrenal hyperplasia.

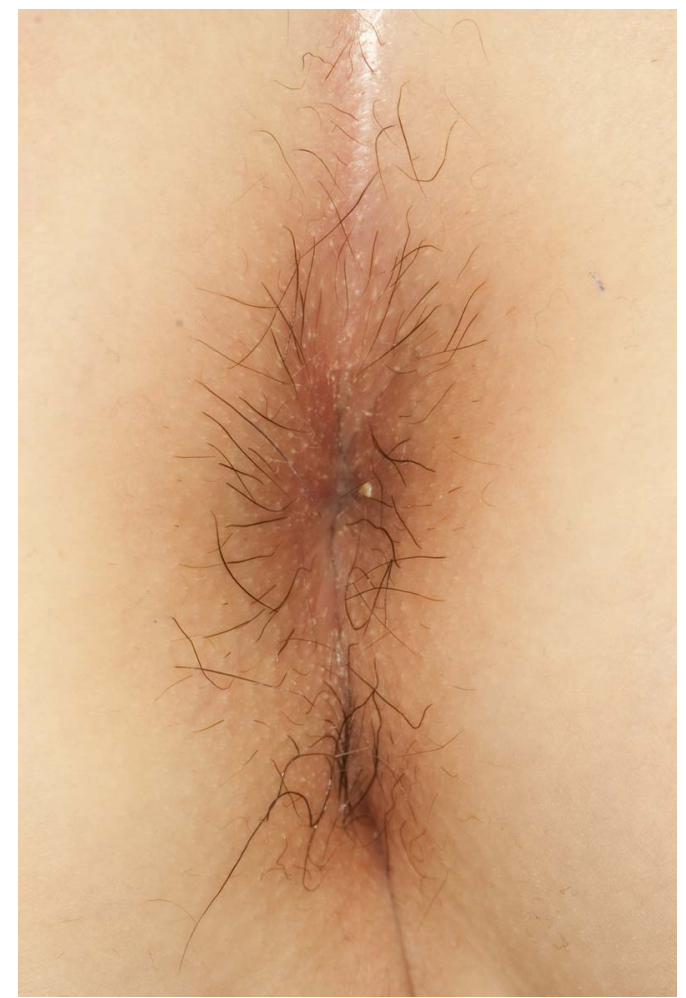

Figure 1 Presence of dark and coarse hairs in the perianal area in this 6-year-old girl prompted investigations to diagnose non-classical congenital adrenal hyperplasia.

Contributors All the authors have equal and significant contribution in the management and reporting of this patient's interesting presentation.

Competing interests None.

Patient consent Obtained.

Provenance and peer review Not commissioned; externally pee reviewed.

\section{REFERENCE}

1 Speiser P, White P. Congenital adrenal hyperplasia. N Engl J Med 2003:349:776-88. 
Copyright 2013 BMJ Publishing Group. All rights reserved. For permission to reuse any of this content visit http://group.bmj.com/group/rights-licensing/permissions.

BMJ Case Report Fellows may re-use this article for personal use and teaching without any further permission.

Become a Fellow of BMJ Case Reports today and you can:

- Submit as many cases as you like

- Enjoy fast sympathetic peer review and rapid publication of accepted articles

- Access all the published articles

- Re-use any of the published material for personal use and teaching without further permission

For information on Institutional Fellowships contact consortiasales@bmjgroup.com

Visit casereports.bmj.com for more articles like this and to become a Fellow 